\title{
LATE HOLOCENE SEDIMENTOLOGY AND PALAEOENVIRONMENT OF KILULI SWAMP, MOUNT KENYA
}

\author{
Olago, D.O. ${ }^{1}$, Street-Perrott, F.A. ${ }^{2}$, Perrott, R.A. ${ }^{2}$, and Odada, E.O. ${ }^{1}$ \\ *Department of Geology, University of Nairobi, PO Box 30197, Nairobi, Kenya \\ ${ }^{2}$ Department of Geography, University of Wales Swansea, Wales, UK
}

\begin{abstract}
Kiluli Swamp is an extensive valley swamp near the lower limit of the montane forest on the eastern slopes of Mount Kenya, East Africa. The swamp is fed by a small spring on the northeastern margin, and the water table lies a few centimetres below the surface. The swamp's sediments modify water chemistry: the $\mathrm{Na}-\mathrm{Mg}-\mathrm{HCO}_{3}$ water-type at the input changes to a Ca$\mathrm{Mg}-\mathrm{HCO}_{3}$ water-type in the central parts of the swamp. A short sediment core $(2.12 \mathrm{~m})$ was retrieved from the central part of the swamp using a modified Livingstone piston corer. The sediments were mainly composed of silty organic mud, silty clay and coarse silt. Three radiocarbon dates were obtained. A suite of sedimentological analyses was carried out in order to reconstruct the palaeoenvironmental history of the area, and these included: mineral magnetic characteristics (susceptibility, IRM etc.); total organic carbon (TOC); total nitrogen (TN), and stable carbon isotopes. The sediment record stretches from about 4,000 yr BP (before present) to present. Indications are that the valley was initially dry and the catchment vegetation was characterised by dominant $\mathrm{C}_{4}$-type grassland. The initiation of true swamp conditions occurred at ca.470 $\mathrm{yr}$ $B P$ immediately following a phase of deep ponding and high diatom productivity within the swamp between 600 and $470 \mathrm{yr}$ BP. A high incidence of charcoal from 470 to $0 \mathrm{yr}$ BP probably marks the period of persistent anthropogenic activities within the catchment. There is a change in vegetation type from a predominantly $C_{4}$-type to predominantly $C_{3}$-type at about $130 \mathrm{yr} B P$ that is attributed to crop cultivation within the swamp rather than due to climate change, since the arid phase which marks this zone would have, under natural conditions, abetted the continued dominance of $C_{4}$ plants which are more drought-resistant than $C_{3}$ plants. The changes observed are broadly synchronous with other palaeoenvironmental records from Mount Kenya and the surrounding region.
\end{abstract}

\section{INTRODUCTION}

Mount Kenya lies on the equator at about $37^{\circ} \mathrm{E}$ (Figure 1). It is an extinct, heavily denuded volcano that lies in a zone of predominantly easterly winds characterised by two well-marked monsoon seasons, the northeast monsoon from December to March and the southeast monsoon from June to October (Thompson, 1966). Mean annual rainfall varies from about 1,015 to $1,270 \mathrm{~mm}$ in the foothill areas (Survey of Kenya, 1970) to over $2,000 \mathrm{~mm}$ in the Montane Forest Zone (alt. ca.1,800 to $2,400 \mathrm{~m}$ ) and declining to $c a .1,015 \mathrm{~mm}$ in the Alpine Zone (Thompson, 1966). Annual-mean maximum temperatures are generally less than $22^{\circ} \mathrm{C}$ and these decrease with increasing altitude. The annual-mean minimum temperatures are 10 to $14^{\circ} \mathrm{C}$ on the footslopes, and less than $6^{\circ} \mathrm{C}$ in the nival zone (Survey of Kenya, 1970). The annual-mean maximum temperatures are 22 to $26^{\circ} \mathrm{C}$ at the footslopes, and less than $18^{\circ} \mathrm{C}$ in the nival zone. Diurnal temperature variations are much more pronounced than variations in mean annual temperatures (Survey of Kenya, 1970).

The mountain exhibits vegetation zonation of a similar type to that of the other highland regions of East Africa (Hedberg, 1951; Coe, 1967). The lowermost zone, which extends up to the lowermost edges of the Mt. Kenya forest at altitudes between 1,000 to $2,000 \mathrm{~m}$ is the cultivated or pastoral zone (Baker, 1967). It replaces the natural transition zone which one would expect to find connecting the Afromontane Belt and lowland phytochoria (White, 1983). The typical vegetation consists of Themeda 


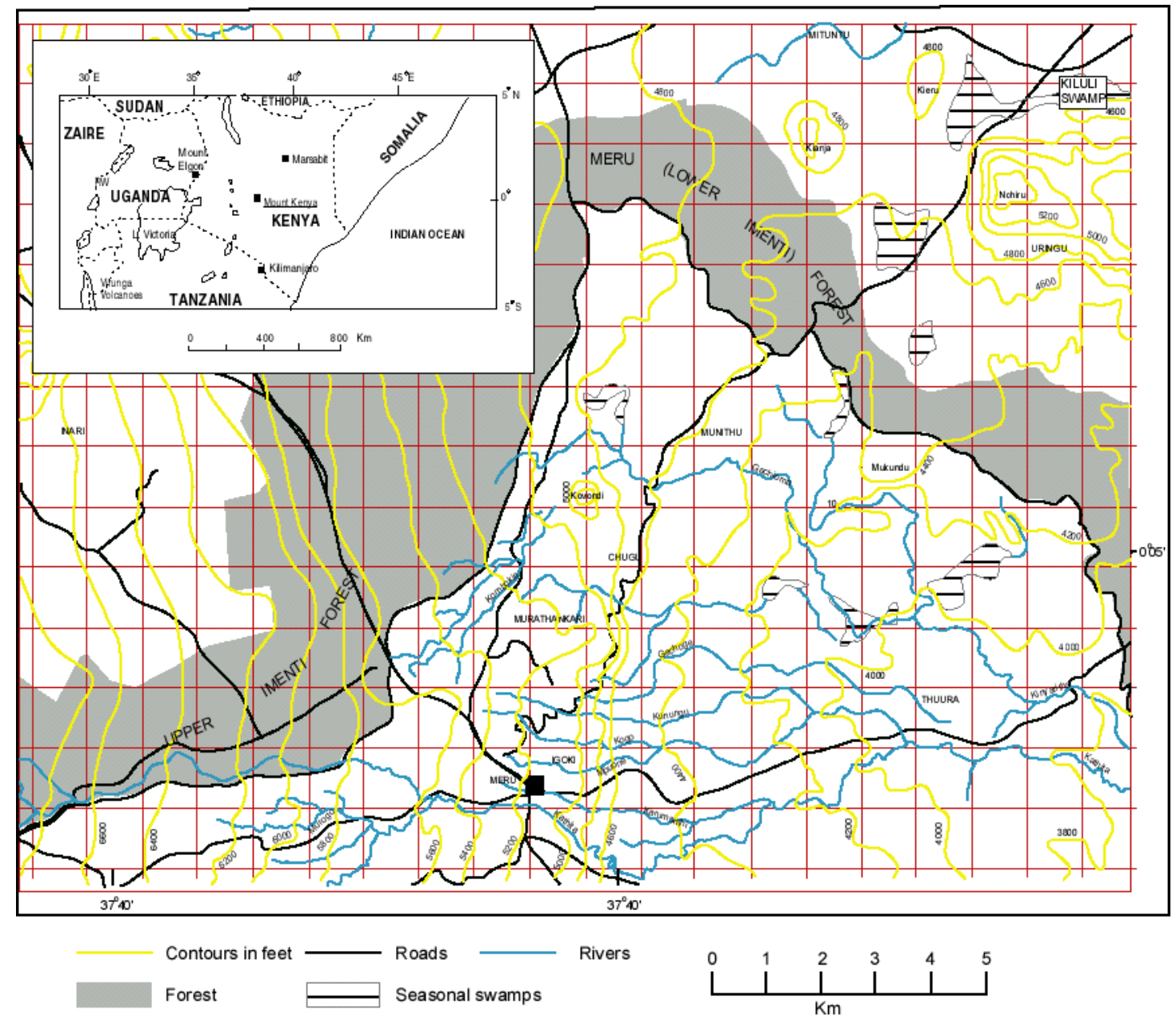

Figure 1. Location of Mount Kenya and Kiluli Swamp, Kenya

grassland to the west and scattered Acacia savanna elsewhere (Coetzee, 1967). Gallery forest comprised of trees such as Syzygium cordatum, Podocarpus gracilior and Erica arborea is found along stream channels radiating from the mountain (Coetzee, 1967). The Montane Forest Zone generally lies between $c a .1,980$ and 3,000m a.s.l. (Ojany and Ogendo, 1973), and extends up to levels of $c a .3,350 \mathrm{~m}$ on the west and south sides, and ca.3,000m on the eastern and northern sides (Baker, 1967; Ojany and Ogendo, 1973). The forest can be distinguished into two types: Humid Forest which occurs on the northeast, east and south slopes, and Dry Montane Rain Forest on the west and northwest slopes (Coetzee, 1967). The Humid Forest is characterised by tree species such as camphor (Ocotea usambariensis), Myrica salicifolia, Pygeum (Prunus) africanum, Macaranga kilimandscharica, and patches of Podocarpus milanjianus (Coetzee, 1967; Ojany and Ogendo, 1973) and reaches its maximum development on the southeast sector of the mountain (Baker, 1967; Ojany and Ogendo, 1973). The Dry Montane Rain Forest is mainly characterised by Juniperus procera (Cedar), Podocarpus milanjianus, Olea africana, O. hochstetteri, Maytenus undatus, Neoboutonia macrocalyx, and Cassipourea malosana (Coe, 1967; Coetzee, 1967; Ojany and Ogendo, 1973). The Bamboo Zone (comprised of Arundinaria alpina) occurs between 2,800 and 3,300m. The HageniaHypericum Zone is generally narrow and well-defined. The levels of this zone are $c a .3,200 \mathrm{~m}$ to $3,300 \mathrm{~m}$ on the west and 2,900m to 3,000m on the east, but small patches occur higher in sheltered valleys (Baker, 1967; Coe, 1967). At approximately 3,000m there is another gradual 
D. O. Olago

change to a shrubby moorland dominated by Philippia trimera and Erica sp., Helichrysum sp. and several other shrubs, as well as species of the sub-genus Dendrosenecio (giant groundsel) (Baker, 1967; Flenley, 1979) which together form the Ericaceous zone. The Alpine Zone shows an altitudinal vegetation transition culminating in a narrow nival zone (Coe, 1967). The Alpine Zone is open, with often marshy ground, and is characterised by Dendrosenecio, Alchemilla shrubs and Helichrysum (everlasting flowers).

Kiluli Swamp ( $0^{\circ} 08^{\prime} \mathrm{N}, 37^{\circ} 45^{\prime} \mathrm{E}$, altitude $1020 \mathrm{~m}$ a.s.l) is a valley swamp near the lower limit of the montane forest east of Meru where mean annual rainfall is $c a .1,020 \mathrm{~mm}$ (Figure1). It is an extensive valley swamp with no surface water: across it runs a flowing water channel fed by a spring situated at the northeast edge of the swamp. The water table lies just a few centimetres beneath the surface.

\section{MATERIALS AND METHODS}

The swamp water was analysed in the field for temperature, $\mathrm{pH}$ and conductivity (using temperature, $\mathrm{pH}$ and conductivity meters respectively), alkalinity (Hach kit) and dissolved oxygen content (Merck kit). Sample 1 was taken from a flowing water channel fed by a spring at the northeast edge of the swamp. Sample 2 (representative of interstitial waters in the swamp) was taken from a man-made drainage ditch near the centre of the swamp, close to the sediment coring site.

Two sediment cores (KS1 - 2.12m and KS2 - 2.34m) were retrieved from the central part of the swamp, and the observable lithology was described in the field. They were then wrapped and placed in hard plastic tubes for transportation, and were stored at $4^{\circ} \mathrm{C}$ at University of Oxford. Laboratory analyses included determination of: detailed lithology, bulk density, mineral magnetic parameters, total carbon and nitrogen contents, and stable carbon isotope ratios.

\section{Core Chronology}

Three AMS radiocarbon dates have been obtained for core KS1 (Table 1).

Table 1. ${ }^{14} \mathrm{C}$ dates for the Kiluli core KS1 (uncalibrated)

\begin{tabular}{|l|l|}
\hline Depth $(\mathrm{cm})$ & $14 \mathrm{C}$ years BP \\
\hline 40 & $130 \pm 50$ \\
\hline 98 & $480 \pm 45$ \\
\hline 197 & $3,345 \pm 50$ \\
\hline
\end{tabular}

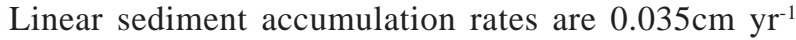
between 197 and $98 \mathrm{~cm}, 0.166 \mathrm{~cm} \mathrm{yr}^{-1}$ between 98 and $40 \mathrm{~cm}$, and $0.308 \mathrm{~cm} \mathrm{yr}^{-1}$ from 40 to $0 \mathrm{~cm}$. Extrapolating the sediment accumulation rate to the base of the core yields an age of 3,970 yr BP. The lithostratigraphic changes occur at 3,288 yr BP $(195 \mathrm{~cm}), 2,800$ yr BP $(178 \mathrm{~cm}), 2,245 \mathrm{yr}$ BP $(162 \mathrm{~cm}), 470 \mathrm{yr}$ BP $(97 \mathrm{~cm})$ and 120 yr BP $(37 \mathrm{~cm})$.

\section{RESULTS}

\section{Water Chemistry}

The water is weakly acidic ( $\mathrm{pH} 6.3$ to 6.7) with a fairly uniform temperature of about $22^{\circ} \mathrm{C}$ due to its very shallow depth (Table 2).

Kiluli Swamp water chemistry is distinctively different at the two sample sites, and is a pointer to the fact that different factors can be attributed to their respective chemical characteristics. Sample 1, taken from a flowing water channel fed by a spring at the northeast edge of the swamp, reflects the characteristics of the groundwater inflow to the swamp. The core site sample 2 is reflective of the in situ modification of the chemistry of the inflow waters within the swamp itself. It is characterised by intermediate dissolved oxygen concentrations in the spring channel water, and anoxic interstitial water. The cation loadings are: $\mathrm{Na}>\mathrm{Mg}>\mathrm{Ca}>\mathrm{K}>\mathrm{Fe}$ at the Sample 1 site, and $\mathrm{Ca}>\mathrm{Mg}>\mathrm{K}>\mathrm{Na}>\mathrm{Fe}$ at the core site (Table 2). Anion loadings are $\mathrm{HCO}_{3}>>\mathrm{Cl}>\mathrm{NO}_{3}>\mathrm{PO}_{4}$ at the sample 1 site, and $\mathrm{HCO}_{3}>>\mathrm{Cl}>\mathrm{SO}_{4}>\mathrm{NO}_{3}>\mathrm{PO}_{4}$ at the core site. The water therefore changes from a Na-Mg- $\mathrm{HCO}_{3}$ type near input sources, to a $\mathrm{Ca}-\mathrm{Mg}-\mathrm{HCO}_{3}$ type within the central parts of the swamp (Table 2). The very low concentration of $\mathrm{Na}$ at the sample 1 site, contrasted with the relatively high concentration of $\mathrm{Ca}$ at the core site, suggests that as the groundwater moves into the swamp, $\mathrm{Na}$ may be replacing $\mathrm{Ca}$ and $\mathrm{Mg}$ at the exchangeable sites on clay minerals, thus increasing the concentrations of $\mathrm{Ca}$ and $\mathrm{Mg}$ in solution, while the concentration of $\mathrm{Na}$ decreases. This interaction is supported by the chemical equilibria calculations (PCWATEQ; Truesdell and Jones, 1974). Some nitrate and phosphate are supplied to the lake by the groundwater inflows, and these nutrient ions are quickly taken up by active organisms, resulting in their depletion within the swamp. There appears to be some production of authigenic sulphate within the swamp (Table 1). It may be as a result of the reaction between ferric iron and $\mathrm{H}_{2} \mathrm{~S}$ produced by decaying organic matter, resulting in the reduction of $\mathrm{Fe}^{3+}$ to $\mathrm{Fe}^{2+}$ and the formation of $\mathrm{SO}_{4}{ }^{2-}$ ions (Brownlow, 1979), and/or may reflect anthropogenic pollution. 
Late Holocene Sedimentology and Palaeoenvironment of Kiluli Swamp, Mount Kenya

Table 2. Water chemistry of Kiluli Swamp at core site and sample 1 site

\begin{tabular}{|c|c|c|c|c|c|}
\hline Sample Site & Details & $\mathrm{pH}$ & $\begin{array}{c}\text { Temperature } \\
\left({ }^{\circ} \mathrm{C}\right)\end{array}$ & $\begin{array}{c}\text { Conductivity } \\
\text { (uS/cm) }\end{array}$ & $\begin{array}{c}\text { Oxygen } \\
(\mathrm{mg} / \mathrm{l})\end{array}$ \\
\hline \multirow{2}{*}{$\begin{array}{l}\text { KILULI } \\
\text { SWAMP }\end{array}$} & Sample 1 & 6.7 & 22.1 & 150 & 4.5 \\
\hline & Sample 2 & 6.3 & 21.8 & 195 & BDL \\
\hline
\end{tabular}

\begin{tabular}{|l|l|c|c|c|c|c|c|}
\hline Sample Site & Details & $\begin{array}{c}\mathrm{Ca} \\
(\mathrm{meq} / \mathrm{l})\end{array}$ & $\begin{array}{c}\mathrm{Mg} \\
(\mathrm{meq} / \mathrm{l})\end{array}$ & $\begin{array}{c}\mathrm{Na} \\
(\mathrm{meq} / \mathrm{l})\end{array}$ & $\begin{array}{c}\mathrm{K} \\
(\mathrm{meq} / \mathrm{l})\end{array}$ & $\mathrm{Ca}(\%)$ & $\mathrm{Mg}(\%)$ \\
\hline \multirow{2}{*}{$\begin{array}{l}\text { KILULI } \\
\text { SWAMP }\end{array}$} & Sample 1 & 0.17 & 0.428 & 0.304 & 0.044 & 18 & 45 \\
\cline { 2 - 8 } & Sample 2 & 0.719 & 0.658 & 0.087 & 0.065 & 47 & 43 \\
\hline
\end{tabular}

\begin{tabular}{|l|l|c|c|c|c|c|c|}
\hline Sample Site & Details & $\begin{array}{c}\mathrm{Cl} \\
(\mathrm{meq} / \mathrm{l})\end{array}$ & $\begin{array}{c}\mathrm{SO}_{4} \\
(\mathrm{meq} / \mathrm{l})\end{array}$ & $\begin{array}{c}\text { Alkalinity } \\
(\mathrm{meq} / \mathrm{l})\end{array}$ & $\begin{array}{c}\mathrm{Cl} \\
(\%)\end{array}$ & $\begin{array}{c}\mathrm{SO}_{4} \\
(\%)\end{array}$ & $\begin{array}{c}\text { Alkalinity } \\
(\%)\end{array}$ \\
\hline \multirow{2}{*}{$\begin{array}{l}\text { KILULI } \\
\text { SWAMP }\end{array}$} & Sample 1 & 0.073 & 0 & 1.3 & 5 & 0 & 95 \\
\cline { 2 - 8 } & Sample 2 & 0.085 & 0.008 & 1.74 & 5 & 0 & 95 \\
\hline
\end{tabular}

\section{Stratigraphy}

Five lithological units are recognised; silty clays, coarse silts, silty organic mud, porous fibrous peats and a root mat unit (Figure 2). There are also fibrous plant macrofossils above $125 \mathrm{~cm}$. The sediments are nondiatomaceous except at 103 to $97 \mathrm{~cm}$. The five lithological units are divided into three zones: the silty clay and coarse silt beds (212-162cm); the silty organic mud bed (162$97 \mathrm{~cm})$; and the porous fibrous peat $(97-0 \mathrm{~cm})$.

The Silty Clay and Coarse Silt Beds (Zone 3: 212 $162 \mathrm{~cm})$

Clastic, non-diatomaceous sediments are dominant from 212 to $162 \mathrm{~cm}$ : silty clay sediments sandwich a coarse silt bed between 195 and 178cm (Figure 2). The change from silty clay to a coarse silt bed at $195 \mathrm{~cm}$ is marked by a gradual boundary. The sediments in this zone are stained with yellow-brown Fe oxides which probably indicate the prevalence of limonite and goethite within the sediments.

\section{The Silty Organic Mud Bed (Zone 2: 162-97cm)}

These sediments (162 to $97 \mathrm{~cm}$ ) show some textural variations. From 162 to $130 \mathrm{~cm}$ silty organic clay sediments occur. From 162 to $130 \mathrm{~cm}$, organic matter is contained within the sediments. The Fe staining observed in Zone 3 continues in this zone upto $130 \mathrm{~cm}$. The sediments above $130 \mathrm{~cm}$ are organic-matter rich. From
130 to $112 \mathrm{~cm}$ a black, silty organic mud with occasional very fine fibrous macrofossils occurs, and a clear boundary demarcates it from a grey silty organic clay at 112 to $103 \mathrm{~cm}$ (Figure 2). Between 103 to $97 \mathrm{~cm}$ the sediments are characterised by a black silty organic mud bed (similar to that at 130 to $112 \mathrm{~cm}$ ) and contain occasional fine fibrous macrofossils as well as a rich diatom assemblage. The diatom assemblage includes Navicula confervacea, Synedra ulna, Pinularia (acrosphaeria), Cyclotella (meneghiniana), Gomphonema (gracile), Nitzschia and Eunotia sp. (A. Parkes, pers. comm.).

\subsubsection{The Porous Fibrous Peat (Zone 1: 97-0cm)}

From 97 to $0 \mathrm{~cm}$ the sediments are comprised of a soft, porous, fibrous peat with common medium size to large hairlike macrofossils between 97 and $38 \mathrm{~cm}$, and abundant medium-sized macrofossils from 36 to $0 \mathrm{~cm}$ (Figure 2). A root mat containing very large, fibrous plant macrofossils and marked by abrupt, irregular upper and lower boundaries occurs between 38 and $36 \mathrm{~cm}$ (Figure 2).

\section{Dry Bulk Density and Moisture Content}

Dry bulk density (DBD) values are generally low and decrease from $1.14 \mathrm{~g} / \mathrm{cm}^{3}$ at the base of the core to $0.07 \mathrm{~g} /$ $\mathrm{cm}^{3}$ at the top, while moisture content increases upwards from about $40 \%$ at the base to $>90 \%$ at the top (Fig. 3). Water contents span a range of 40 to $98 \%$ (Fig.3). The lowest values, averaging ca.50\% are found between 212 


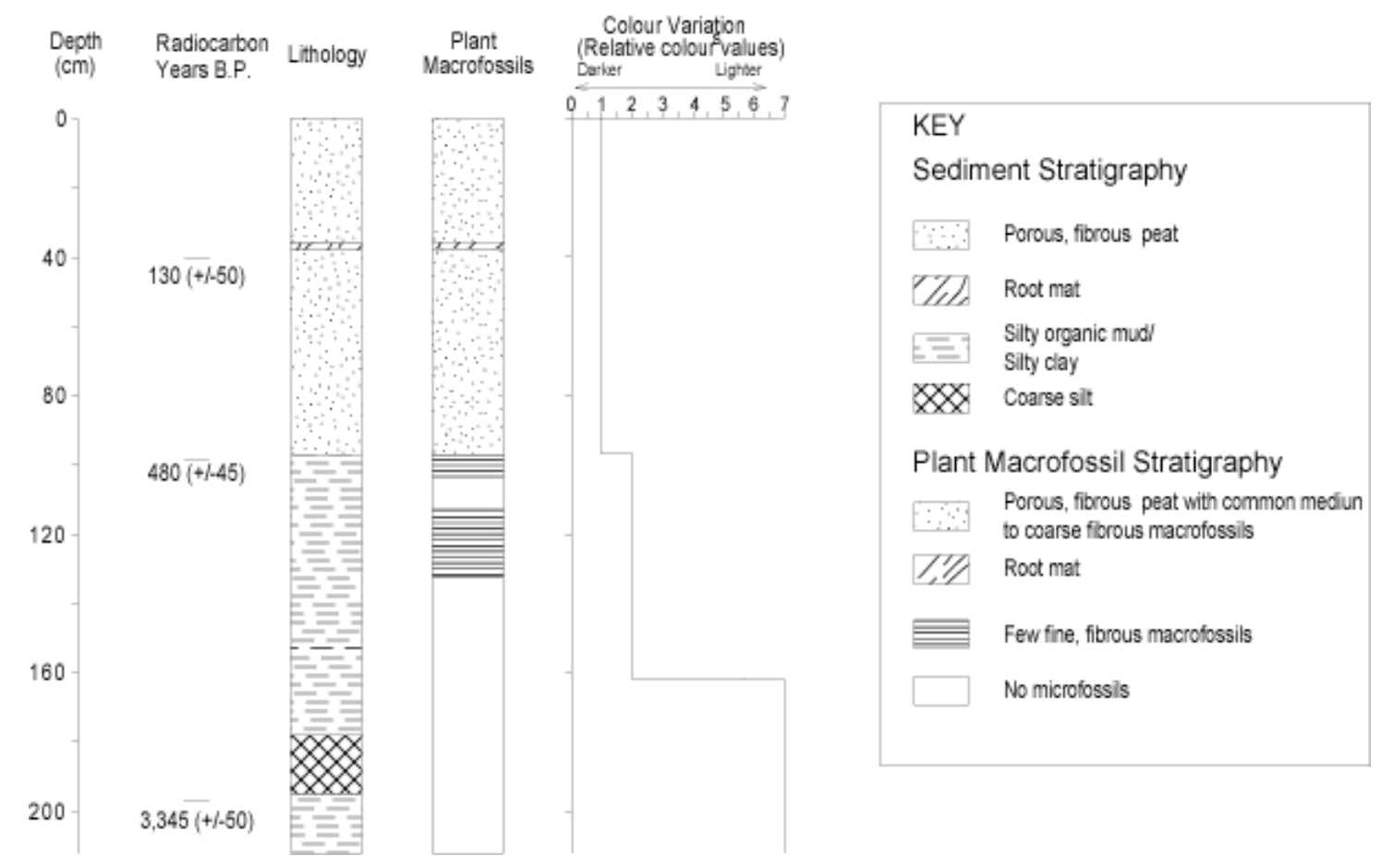

Figure 2. Stratigraphy of core KS1. Relative colour values are assigned as outlined in Olago (1995)

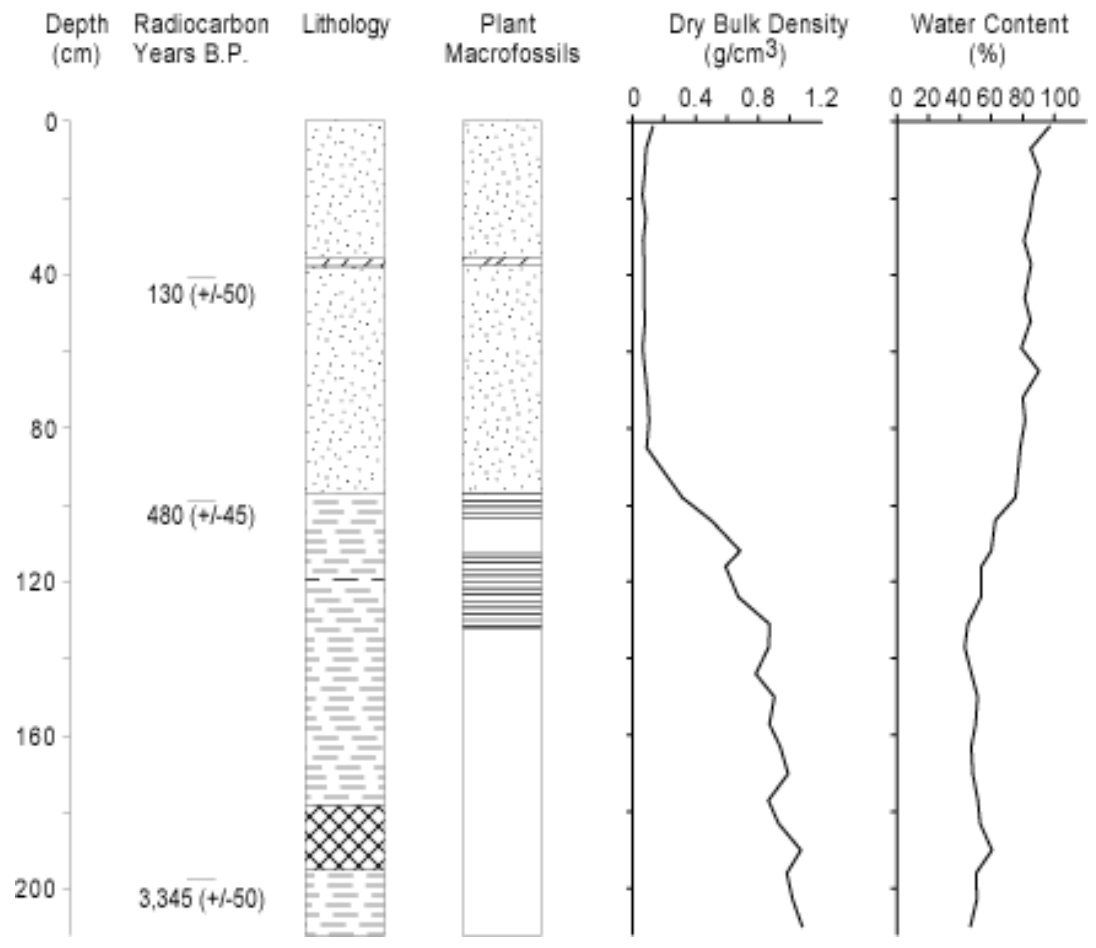

Figure 3a. Dry bulk density and water content in core KS1 


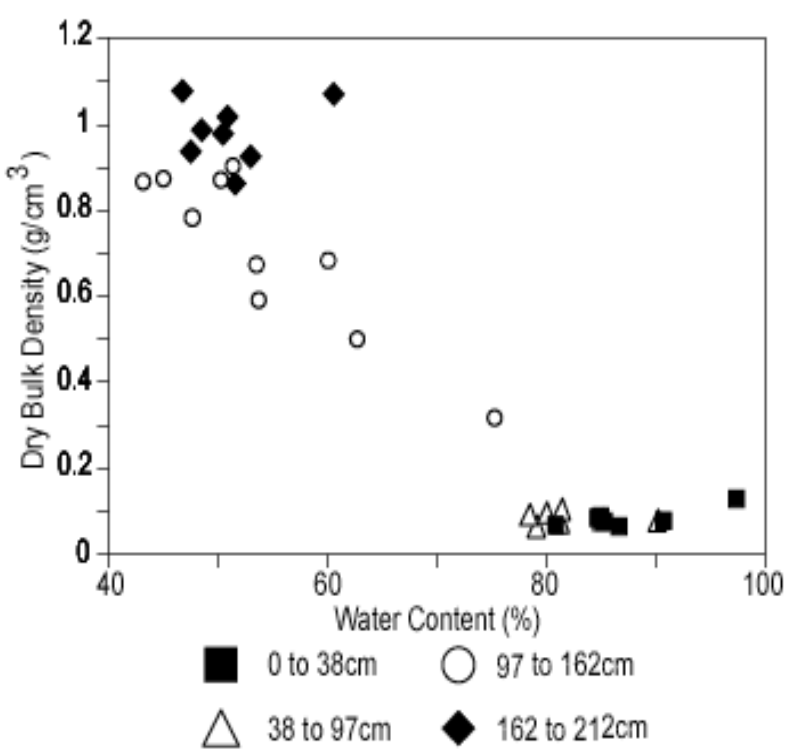

Figure 3b Bulk sediment features and characteristics of Kiluli Swamp sediments

and $128 \mathrm{~cm}$ with a positive peak at $192 \mathrm{~cm}(60 \%)$ and a low at $138 \mathrm{~cm}(42 \%)$. Between 128 and $100 \mathrm{~cm}$ water contents increase from 50 to $76 \%$, and from 100 to $2 \mathrm{~cm}$ further increases from 76 to $98 \%$ are recorded (Fig.3).

Changes in the DBD values and water contents reflect the sediment characteristics, higher DBD values and corresponding lower water contents are thus found in the more clastic, inorganic sediments while lower values are found in the peats. No significant correlations are observed between DBD and water content save for the sediments between 162 and 97cm (Fig.3). These sediments have a strong negative correlation $(r=-0.91)$ between DBD and water content, and are transitional between the high density sediments at the base and the low density sediments at the top of the core (Fig.3). The change in DBD from higher to lower values (and vice

versa for the water content) marks the change from a dry to wet environment in Kiluli valley (Figs.8.2 and 8.3). The gradual increase in water contents from 97 to $0 \mathrm{~cm}$ and the almost invariant DBD values within this zone indicate that the trends in the water content are mainly a factor of reduced sediment autocompaction with decreasing depth (Fig.3).

\section{Mineral Magnetic Features}

The mineral magnetic concentrations are highest within the more clastic sediments from 212 to $85 \mathrm{~cm}$, and in the top $45 \mathrm{~cm}$ (Figs.4 and 5).
Highest magnetic mineral concentrations occur within the coarse silt bed at 195 to $178 \mathrm{~cm}$, and within the top $4 \mathrm{~cm}$. The correlation of $\chi$ and SIRM with DBD is not significant. However, in the low density organic sediments above $97 \mathrm{~cm}$, large variations in both $\chi$ and SIRM at invariant DBD values indicate changing proportions in the types and overall concentrations of magnetic minerals present (i.e. superparamagnetic, singledomain magnetites, or paramagnetic minerals (including haematite). Relatively smaller ranges in the values occur between 212 to $97 \mathrm{~cm}$, but the range in SIRM values is large indicating the importance of haematite and goethite contributions within this zone (Fig.5). The SIRM and $\chi$ have a regression coefficient of 0.76 and a ratio of $c a .8 \mathrm{kAm}^{-1}$, and reflects a strong influence of magnetite in the sediments (Fig.6) (cf. Thompson and Oldfield, 1986). Principal components analysis shows that most of the variance in the data set is explained by the first two components (91\% and 7\% respectively) (Fig.5).

The first principal component (PC1) reflects the total concentration of magnetic minerals within the sediments, and mirrors the SIRM trend. The much higher scores at the top compared to the bottom of the core (as opposed to the SIRM curve which shows similar magnitude concentrations) is attributed to an artificially high weighting of magnetite due to the inclusion of $\chi$ and $\chi_{\mathrm{fd}}$ which solely reflect the magnetite content of the sediments (Fig.4). The second principal component shows the influence of high haematite and goethite concentrations, most marked between 212 and $162 \mathrm{~cm}$. This is reflected in the normalised curves which show high concentrations of haematite and goethite from 212 to $162 \mathrm{~cm}$, especially in the coarse silt bed (up to 80\%), and the 'hard' IRM (HIRM) concentrations (Fig.5). Although haematite is ubiquitous within the whole core, goethite makes significant contributions only up to $130 \mathrm{~cm}$.

Normalised mineral magnetic IRM, and the HIRM values between 212 and $162 \mathrm{~cm}$ indicate that the magnetic signal in this zone is dominated by haematite/goethite, especially in the coarse silt bed where the relative proportions are up to $80 \%$, and HIRM has values up to $200 \times 10^{-5} \mathrm{Am}^{3} \mathrm{~kg}^{-}$ ${ }^{1}$ (Fig.5). Below $16 \mathrm{~cm}$, haematite and goethite dominate the magnetic mineral signature ( $>50 \%)$ (Fig.5). The sharpest changes in magnetic mineral concentrations tend to occur at boundary positions and can be related to changes in the influx rates of magnetic minerals (and more generally, allochthonous material) to the swamp, as facilitated by unstable environmental and climatic conditions. Maximum goethite concentrations occur within the coarse silt bed (195 to $178 \mathrm{~cm})$, where it contributes $20 \%$ of the SIRM signal. Its presence suggests 


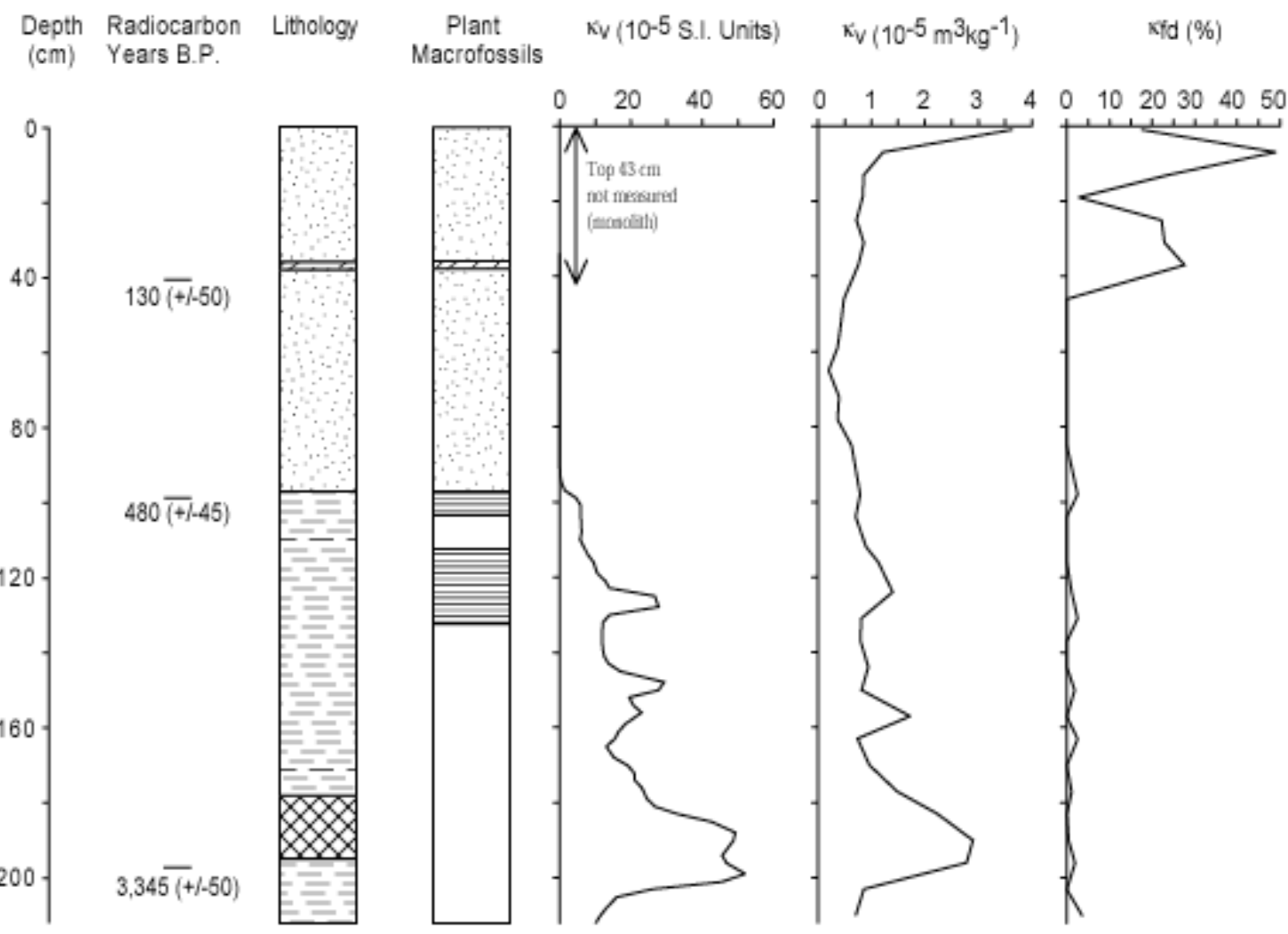

Figure 4. Trends in magnetic susceptibilities by depth, core KS1. $\kappa_{v}$ - volume susceptibility; $\kappa$ - mass specific susceptibility; $\kappa_{\mathrm{fd}}$ - dual frequency susceptibility
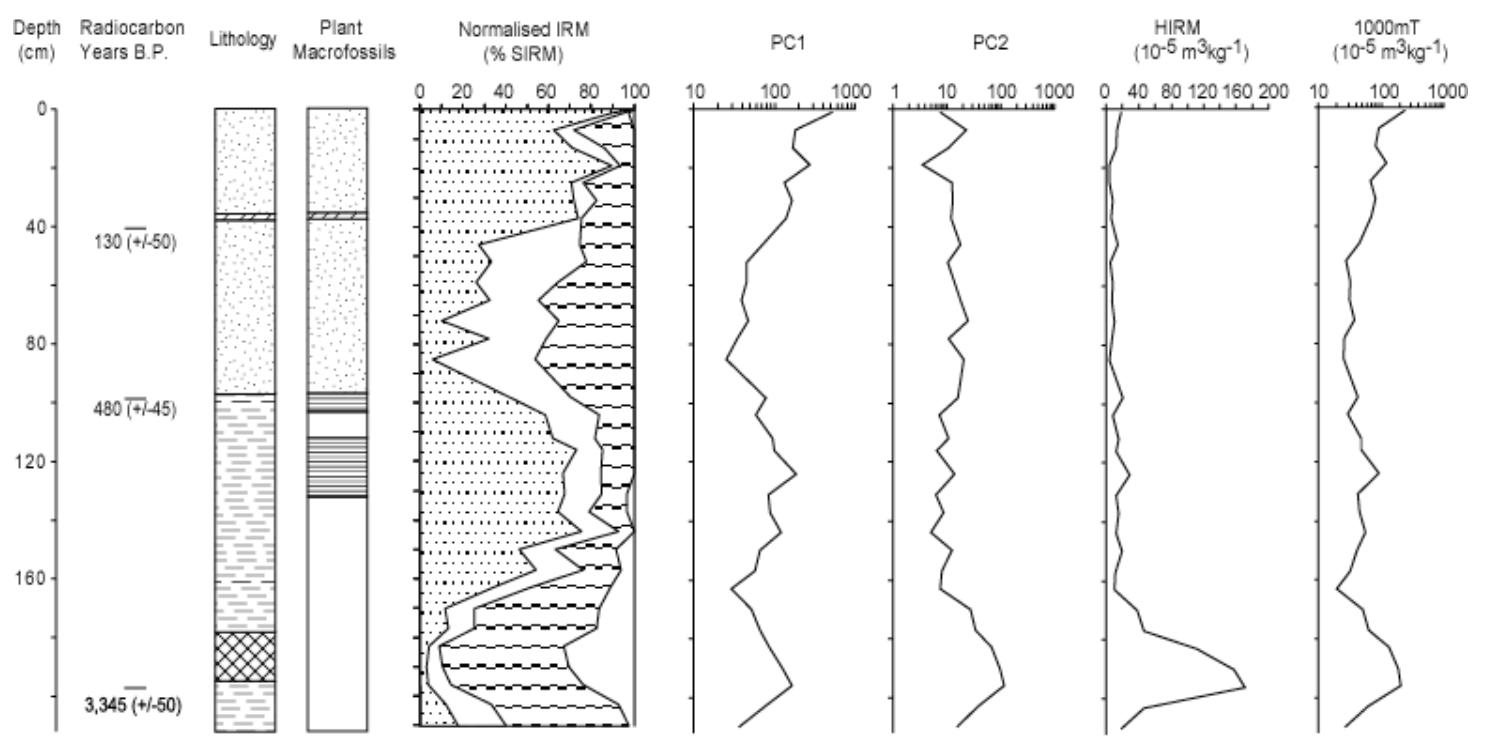

Figure 5. Summary diagrams of isothermal remanent magnetism properties and principal components analysis in core KS1 
that the swamp was well-drained and climatic conditions were generally mild, especially between 195 and $178 \mathrm{~cm}$ (cf. Thompson and Oldfield, 1986). High concentration gains in the 100 to $300 \mathrm{mT}$ field within the coarse silt bed suggests that there is a high loading of impure magnetite grains.

From 162 to $97 \mathrm{~cm}$, magnetite dominates the magnetic mineral assemblage, averaging ca.80\% (Fig.5). As in the preceding zone (212 to $97 \mathrm{~cm}$ ), the largest changes in the magnetic mineral concentrations occur at boundary positions related to an unstable and changing environment. Goethite concentrations taper off at $130 \mathrm{~cm}$ and may indicate that the climate was becoming drier. The significant contributions of 'soft' magnetite between 163 and $90 \mathrm{~cm}$ can be related to increased soil inputs (Figs.4 and 5).

The generally very low susceptibilities from 97 to $38 \mathrm{~cm}$ can be attributed to an overall reduction in the concentration of magnetite and an increase in haematite/ goethite contents (Fig.5). During this period, then, higher temperatures, good aeration, rapid decomposition of organic matter, and a relatively high $\mathrm{pH}$ within the swamp may account for the increase in haematite ( $c f$. Schwertman and Taylor, 1977) and macrophyte development (Fig.5). Where soils are developed from igneous rocks containing predominantly $\mathrm{Fe}^{2+}$ in magnetite and/or within the silicates, weathering is dominated by hydrolytic and oxidative reactions that result in the formation of haematite and/or goethite (Thompson and Oldfield, 1986).

From 38 to $0 \mathrm{~cm}$, higher magnetite concentrations are indicated by the magnetic mineral parameters (Figs. 4 and 5). A slight increase in magnetite contributions is observed following desiccation at 38 to $36 \mathrm{~cm}$. Soft magnetite concentrations are also significant in this zone, and their insurgence is attributed to geomorphic instability as a result of climate change to lower precipitation indices and slightly enhanced erosion (Figs.4 and 5). The high concentration and domination of the magnetic mineral assemblage by magnetite in the top $4 \mathrm{~cm}$ is not associated with any change in the sediment characteristics and suggests that this is probably an effect of cultivation and concomitant enhanced soil erosion within the swamp area; burning may have also enhanced the susceptibility signal. Le Borgne (1955) showed that the magnetic susceptibility of topsoil is often higher than that of the underlying

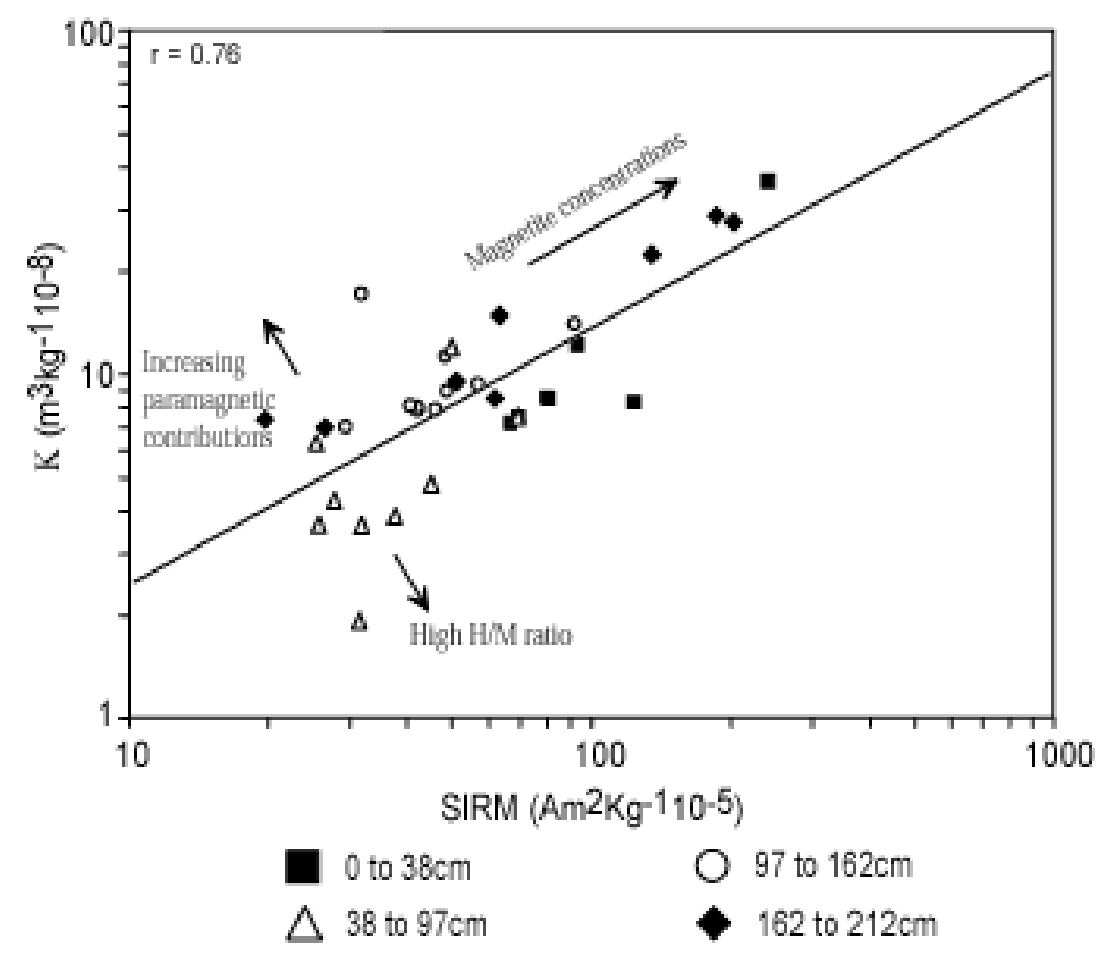

Figure 6. Scatter plot of saturation isothermal remanent magnetism versus magnetic susceptibility, core KS1 
material, and ascribed this to the formation of secondary ferrimagnetic oxides within the clay size fraction of the soil. Burning (generally accepted as a major factor in magnetic enhancement) may partly account for the magnetic enhancement in the surface and near-surface sediments of this zone. Maghaemite is undoubtedly produced by burning (Longworth and Tite, 1977), and non-stoichiometric magnetite may also be formed (Longworth et al., 1979).

\section{Features of the Organic Component}

The TOC contents generally increase from the base of the core to the top (Fig.7). Between 212 and $130 \mathrm{~cm}$ TOC contents are extremely low, averaging $3 \%$. Concentrations increase from 3 to $12 \%$ between 130 and $98 \mathrm{~cm}$. From 98 to $85 \mathrm{~cm}$ a steeper increase (12 to $40 \%$ ) is recorded. A further increase in TOC concentrations is registered from 85 to $19 \mathrm{~cm}$ (40 to 50\%). From 19 to $0 \mathrm{~cm}$ TOC concentrations decrease from 50 to $36 \%$ respectively (Fig.7).

Total nitrogen (TN) concentrations generally increase from the base to the top of the core. Lowest concentrations are recorded between 212 and 203cm (0 to 0.4\%) (Fig.7). From 203 to $185 \mathrm{~cm}$ TN concentrations average $0.4 \%$, and between 185 and $1300 \mathrm{~cm}$ they average $0.5 \%$. Fro M130 to $80 \mathrm{~cm}$ there is a relatively large increase from 0.5 to $2.6 \%$. From 80 to $0 \mathrm{~cm}$, relatively high TN concentrations persist, and lie between 2.4 and 3\% (Fig.7). Higher concentrations are centred at $31 \mathrm{~cm}$ (3.3\%) and $19 \mathrm{~cm}(3.4 \%)$. These trends in the TN concentration mirror the TOC concentrations and can be attributed to similar causes (Fig.7).

From 212 to 203cm C:N ratios are low, generally <1 (Fig.7). Between 203 and $184 \mathrm{~cm}$ a broad peak is recorded with C:N values of 7 to 8 between 197 and $190 \mathrm{~cm}$. From 184 to $65 \mathrm{~cm}$ a gradual increase in the ratios, from 1 to 20 respectively is observed. The $\mathrm{C}: \mathrm{N}$ ratios are $<10$ from 184 to $96 \mathrm{~cm}$, and $>10$ from 96 to $65 \mathrm{~cm}$. From 46 to $0 \mathrm{~cm}$ $\mathrm{C}: \mathrm{N}$ ratios decrease from a peak of 20 to ca.12 respectively; a positive excursion within this zone occurs at $25 \mathrm{~cm}(\mathrm{C}: \mathrm{N}=$ ca.17) (Fig.7).

The $\delta^{13} \mathrm{C}$ values are between -16.2 and -26.8\%o (Fig.7). From 212 to $49 \mathrm{~cm}$ the $\delta^{13} \mathrm{C}$ values are between -21.8 and $-19.9 \%$. From 49 to $40 \mathrm{~cm}$ there is a large shift towards more negative values, i.e. from -19.9 to $-26.8 \%$. From 40 to $0 \mathrm{~cm}$ the $\delta^{13} \mathrm{C}$ values are between -24.3 and $-26.8 \%$ (Fig.7).
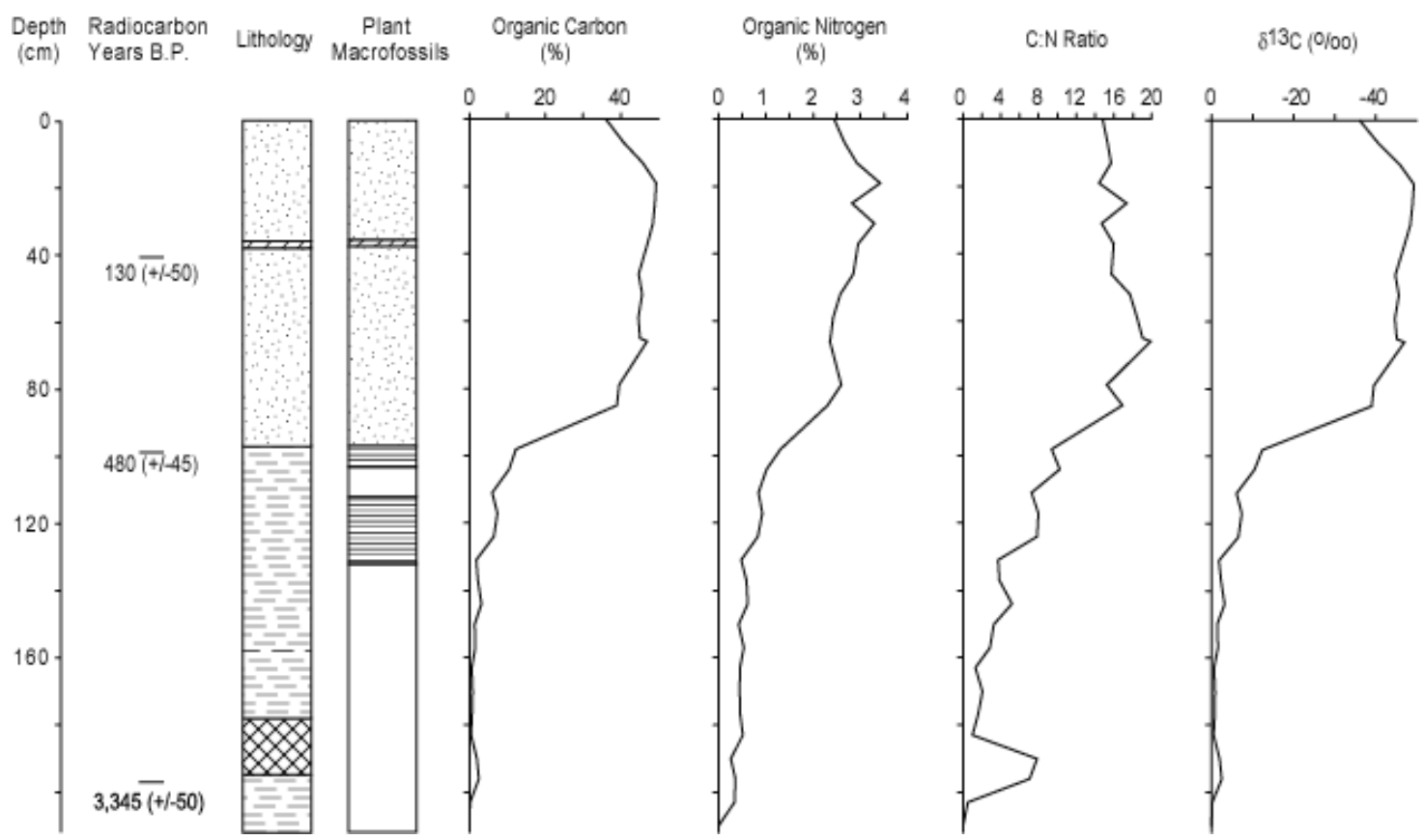

Figure 7. Trends in the organic carbon and nitrogen concentrations, $\mathrm{C} / \mathrm{N}$ ratios and $\delta^{13} \mathrm{C}$ in core $\mathrm{KS} 1$, by depth 
Late Holocene Sedimentology and Palaeoenvironment of Kiluli Swamp, Mount Kenya

TOC is the most dominant organic component and shows a strong positive correlation to organic matter abundance $(\mathrm{C}+\mathrm{H}+\mathrm{N})$. Low TOC contents below $130 \mathrm{~cm}$ reflect the highly clastic nature of the sediments, and little or no productivity within the swamp area (Fig.7).

Low C:N ratios (<8 and in most cases <4) from 212 to $130 \mathrm{~cm}$ reflect the importance of soil organic matter (derived from areas extraneous to the swamp) within the sediments. The higher incidence of charcoal between 140 and $130 \mathrm{~cm}$ reflects the importance of fires (natural or man-made) during this period. Higher C:N ratios (10 to 20) above $96 \mathrm{~cm}$ reflect the importance of macrophyte contributions within the swamp itself. The slight carbon peak at the silty clay - coarse silt boundary (ca.195cm) suggests an episode of increased inputs from the surrounding area. The increases from 163 to $97 \mathrm{~cm}$ ( 1 to $13 \%$ respectively) indicate increasing inputs from locally derived organic material, with largest increases being associated with the zones containing few fine fibrous macrofossils (Fig.7). This trend reflects the encroachment of the swamp by terrestrial vegetation. Deep ponding and probably well aerated waters between 103 and $97 \mathrm{~cm}$ supported a diverse diatom population; this is the only section containing diatoms.

A large change in the carbon and nitrogen contents and the $\mathrm{C}: \mathrm{N}$ ratio occurs at the boundary at $97 \mathrm{~cm}$ and reflects a major hydrological and ecosystem change within Kiluli valley (Fig.7). It represents a marked shallowing of the swamp waters, and encroachment of the swamp by highly productive macrophytes, and thus marks the initiation of swamp conditions within Kiluli valley. The increased incidence of fire is reflected in the relatively higher charcoal contents (1 to $2 \%$ ) and probably reflects anthropogenic disturbance related to cultivation practices in the swamp.

The $\delta^{13} \mathrm{C}$ values show that Kiluli Valley consisted mainly of $\mathrm{C}_{4}$ grasslands between 212 and $49 \mathrm{~cm}$; a mixed $\mathrm{C}_{3}-\mathrm{C}_{4}$ ecosystem existed between 195 and $178 \mathrm{~cm}$ in the section comprised of the coarse silt bed (Fig.7). The transition from the $\mathrm{C}_{4}$-dominated to $\mathrm{C}_{3}$-dominated ecosystem occurred just prior to the desiccation event between 39 and $36 \mathrm{~cm}$, above which the $\mathrm{C}_{3}$ ecosystem is dominant to the present (Fig.7). Since this change from $C_{4}$ to $C_{3}$ ecosystems occurs as an arid event was being approached (and thus one would expect drought-resistant $\mathrm{C}_{4}$ species to persist), this change is most likely due to anthropogenic-related cultivation of $\mathrm{C}_{3}$ plants within the swamp (Fig.7).

\section{PALAEOCLIMATE AND PALAEOENVIRONMENT}

\section{Local}

\section{Zone 3 (212-162cm; 3970 to 2245 yr BP)}

The minerogenic nature of these sediments, and the lack of diatoms (A. Parkes, pers comm.) indicate that it was relatively dry compared to today. The well-defined peak in the $\mathrm{C}: \mathrm{N}$ ratio $(\mathrm{C}: \mathrm{N}=8)$ at about $200 \mathrm{~cm}$, coincides with maximum susceptibility values (high magnetite concentrations) and a shift from fine to coarser detritus. This implies that the material may have accumulated $\mathrm{C}$ and $\mathrm{N}$ under slightly pedogenic conditions, and is supported by magnetic mineral data which show development of haematite and goethite under a hydrolytic and oxidative regime in the area. The presence of goethite additionally suggests that the area was well-drained ( $c f$. Thompson and Oldfield, 1986). These data suggest that during this period, swamp conditions were non-existent. The vegetation in the area consisted of mixed $C_{3}-C_{4}$ type plants.

\section{Zone 2 (162-97cm; 2245-470 yr BP)}

The increasing concentration of organic matter within the sediments, and reduction of goethite concentrations reflecting increasingly poor drainage trends in this zone signifies the progressive development of swamp conditions. It is not clear how this may have been initiated, but it could perhaps be related to progressive silting and consequent damming at the valley outlet. It suggests that vegetation had began to encroach the coring site, but does not unambiguously reflect an increase in humidity in the area. The magnitude of change in TOC (1 to $13 \%$ from $163-97 \mathrm{~cm})$ indicates increasing inputs from locally derived organic material, with largest increases being associated with the zones containing some fine fibrous macrofossils (Fig.7). This trend reflects the encroachment of the swamp by local terrestrial vegetation.

The diatom-rich black silty organic mud bed containing occasional fine fibrous macrofossils between 103 to $97 \mathrm{~cm}$ reflects deep ponding in the swamp, leading to high productivity of aquatic plankton and the development of macrophyte communities. This is the only section containing diatoms. 


\section{Zone 1 (97-0cm; 470-0 yr BP)}

The significant change at $97 \mathrm{~cm}$, marked by the disapearance of diatoms, a large change in the carbon and nitrogen contents and the $\mathrm{C}: \mathrm{N}$ ratio and development of peats reflects a major hydrological and ecosystem change within Kiluli valley. The soft, porous, fibrous peats with common to abundant plant macrofossils indicate high aquatic macrophyte productivity, and the boundary at $97 \mathrm{~cm}$ marks the initiation of true swamp conditions. Lack of diatoms indicate that the water table was below ground level. The generally very low magnetic volume susceptibilities from 97 to $38 \mathrm{~cm}$ can be attributed to an overall reduction in the concentration of magnetite and an increase in haematite/goethite contents (Fig.4). During this period, then, higher temperatures, good aeration, rapid decomposition of organic matter, and a relatively high $\mathrm{pH}$ within the swamp may account for the increase in haematite (cf. Schwertman and Taylor, 1977) and macrophyte development. Mixed $\mathrm{C}_{3}-\mathrm{C}_{4}$ type plants characterised this zone up to about $40 \mathrm{~cm}$.

The root mat between 38 and $36 \mathrm{~cm}$ represents an abrupt dry phase. The $\delta^{13} \mathrm{C}$ values indicate that vegetation shifted sharply from a mixed $\mathrm{C}_{3}-\mathrm{C}_{4}$ to $\mathrm{C}_{3}$ type during this time.

From 36 to $0 \mathrm{~cm}, \mathrm{C}_{3}$ type vegetation is prevalent in the area. A modern day floristic analysis of the low altitude grasslands $(<1500 \mathrm{~m}$ a.s.l.) suggests that nearly all the Poaceae (e.g. Chlorideae, Eragrosteae, Sporoboleae, and Aristideae) are of the $\mathrm{C}_{4}$ photosynthetic type and are associated with low soil moisture (Tieszen et al., 1979). The dominant $\mathrm{C}_{3}$ types therefore reflect an increase in humidity in the region.

The high concentration and domination of the magnetic mineral assemblage by magnetite in the top $4 \mathrm{~cm}$ is not associated with any change in the sediment characteristics and suggests that this is probably an effect of cultivation and concomitant enhanced soil erosion within the swamp area; burning may have also enhanced the susceptibility signal. Le Borgne (1955) showed that the magnetic susceptibility of topsoil is often higher than that of the underlying material, and ascribed this to the formation of secondary ferrimagnetic oxides within the clay size fraction of the soil. Burning (generally accepted as a major factor in magnetic enhancement) may partly account for the magnetic enhancement in the surface and near-surface sediments of this zone. Maghaemite is undoubtedly produced by burning (Longworth and Tite, 1977), and non-stoichiometric magnetite may also be formed (Longworth et al., 1979). Destruction by fire and, more recently, encroachment by agriculturists has raised the lower limit of the indigenous forest of Mount Kenya to its present position (Baker, 1967); cultivation takes place at altitudes up to about 2,300m (Hastenrath, 1973).

\section{Regional}

The dry phase at 4,000 yr BP reflected by an increase in Podocarpus pollen at Sacred Lake and the Hohnel valley mire (alt.4,265m) (Perrott, 1982), is correlated with the prevalence of mixed $\mathrm{C}_{3}-\mathrm{C}_{4}$ plants at Kiluli Swamp. Climate became progressively more humid at Kiluli valley from 2,245 to $470 \mathrm{yr}$ BP. True swamp conditions were initiated at $c a .470 \mathrm{yr}$ BP immediately following ponding of the valley. This correlates with the advent of sedge peat in lake Nkunga at ca.510 yr BP and reflects a slightly arid event. $\mathrm{AC}_{4}$-ecosystem was dominant in Kiluli Swamp until $130 \mathrm{yr} \mathrm{BP}$, following which $\mathrm{C}_{3}$-ecosystems were became dominant. The high incidence of charcoal in Kiluli Swamp probably reflects anthropogenic fires, and may be related to cultivation practices within the swamp.

The initiation of drier conditions on Mount Kenya at ca.4,000 yr BP, indicated by an increase in Podocarpus pollen at Sacred Lake and the Hohnel valley mire (alt.4,265m) (Perrott, 1982), and by a shift towards more positive $\delta^{13} \mathrm{C}$ values in the Sacred Lake (Olago et al., 1999) and $C_{4}$ plants in Kiluli Swamp, is also evident at other sites from pollen records: dry montane forest taxa replaced wet montane forest taxa in the high altitude regions, while at lower altitudes, trees gave way to herbaceous elements. The $\delta^{13} \mathrm{C}$ of palaeosols in a transect from Naivasha to the Mau Escarpment, shows a midHolocene rise $(>300 \mathrm{~m})$ in the altitude of the savannaforest ecotone and reflects the onset of drier conditions in the Naivasha basin (Ambrose and Sikes, 1991). Aucour et al. (1994) observed an increase in $\mathrm{C}_{4}$ plant types from ca.4,500 yr BP in Kashiru, Burundi. A similar observation is made in the Nilgiri Hills, southern India, by Sukumar et al. (1993) for the period 4,700 to 3,000 yr BP. In both cases these changes are attributed to an increase in aridity. These dry conditions generally characterised the rest of the Holocene period.

\section{SUMMARY}

The Kiluli Swamp record covers the late Holocene, from ca.4,000 to 0 yr BP. The valley was initially dry and the catchment vegetation was characterised by dominant $\mathrm{C}_{4}$ type grassland. The initiation of true swamp conditions occurred at ca.470 yr BP immediately following a phase of deep ponding and high diatom productivity within the 
swamp between 600 and $470 \mathrm{yr}$ BP. The high incidence of charcoal from 470 to 0 yr BP probably marks the period of persistent anthropogenic activities within the catchment. The change from $\mathrm{C}_{4}$ - to a $\mathrm{C}_{3}$-type vegetation at ca.130 yr BP is probably due to a change in type of agronomic crops grown within the swamp rather than due to climate change, since the arid phase which marks this zone would have, under natural conditions, abetted the continued dominance of $\mathrm{C}_{4}$ plants which are more drought-resistant than $\mathrm{C}_{3}$ plants.

\section{REFERENCES}

AMBROSE, S.H. and SIKES, N.E., 1991. Soil carbon isotope evidence for Holocene habitat change in the Kenya Rift Valley. Science, 253: 1402-1405.

AUCOUR, A., HILLAIRE-MARCEL, C. and BONNEFILLE, R., 1994. Late Quaternary biomass changes from ${ }^{13} \mathrm{C}$ measurements in a highland peatbog from equatorial Africa (Burundi). Quat. Res., 41: 225233.

BAKER, B.H., 1967. Geology of the Mount Kenya Area. Geol. Surv. Kenya, Rep. 79, Nairobi, 78 pp.

BROWNLOW, A.H., 1979. Geochemistry. Prentice Hall Inc., Englewood Cliffs, N.J. 498 pp.

COE, M.J., 1967. The Ecology of the Alpine Zone of Mount Kenya. Dr. W. Junk Publishers. 136 pp.

COETZEE, J.A., 1967. Pollen analytical studies in East and Southern Africa. Palaeoecol. Afr. 3: 146 pp.

FLENLEY, J.R., 1979. The Equatorial Rain Forest: A Geological History. Butterworth and Co. (Publishers) Ltd., London. 162 pp.

HASTENRATH, S., 1973. Observations on the periglacial morphology of Mts. Kenya and Kilimanjaro, East Africa. Z. Geomorph., N.F., Suppl. Bd., 16: 161-179.

HEDBERG, O., 1951. Vegetation belts of the East African Mountains. Svensk. bot. Tidskr., 45: 140-202.

LE BORGNE, E., 1955. Susceptibilité magnétique abnormale du sol superficiel. Ann. Geophys., 16: 159195.

LONGWORTH, G. and TITE, M.S., 1977. Mossbauer and magnetic susceptibility studies of iron oxides in soils from archaeological sites. Archaeometry, 19: 314.
LONGWORTH, G., BECKER, L.W., THOMPSON, R., OLDFIELD, F., DEARING, J.A. and RUMMERY, T.A., 1979. Mossbauer and magnetic studies of secondary iron oxides in soils. J. Soil Sci., 30: 93-110.

OJANY, F.F. and OGENDO, R.B., 1973. Kenya: A Study in Physical and Human Geography. Longman Kenya Ltd., 227 pp.

OLAGO,D.O., STREET-PERROTT, F.A., PERROTT, R.A., HARKNESS, D.D., IVANOVICH, M. and PARKES, A., 1999. Late Quaternary glacialinterglacial cycle of climatic and environmental change on Mount Kenya, Kenya. Journal of African Earth Sciences, 29 (3): 593-618.

PERROTT, R.A., 1982. A postglacial pollen record from Mount Satima, Aberdare Range, Kenya. In: Amer. Quat. Assoc. Seventh Biennial Conference Seattle, June 1982. Program and Abstracts, 188 pp.

SCHWERTMAN, U. and TAYLOR, R.M., 1977. Iron oxides. In: J.B. DIXON (ed.), Minerals in Soil Environments. Soil Sci. Soc. Am., pp. 145-180.

SUKUMAR, R., RAMESH, R., PANT, R.K. and RAJAGOPALAN, G., 1993. A d ${ }^{13} \mathrm{C}$ record of late Quaternary climate change from tropical peats in southern India. Nature, 364: 703-706.

SURVEY of KENYA, 1970. National Atlas of Kenya, Nairobi, Kenya.

THOMPSON, B.W., 1966. The mean annual rainfall of Mount Kenya. Weather, 21: 48-49.

THOMPSON, R. and OLDFIELD, F., 1986. Environmental Magnetism. Allen and Unwin, London, 227 pp.

TIESZEN, L.L., SENYIMBA, M.M., IMBAMBA, S.K. and TROUGHTON, J.H., 1979. The distribution of $\mathrm{C}_{3}$ and $\mathrm{C}_{4}$ grasses and carbon isotope discrimination along an altitudinal and moisture gradient in Kenya. Oecologia, 37: 337-350.

TRUESDELL, A.H. and JONES, B.F., 1974. WATEQ, a computer programme for calculating chemical equilibria of natural waters. J. Res. U.S. Geol. Surv., 2: 233-248.

WHITE, F., 1983. The Vegetation of Africa. UNESCO, 355 pp. 